\title{
Manajemen Perioperatif pada Perdarahan akibat Atonia Uteri
}

\author{
Budi Yulianto Sarim \\ Smf Anestesiologi dan Terapi Intensif Fakultas Kedokteran Universitas Nusa Cendana/ \\ Rsud Prof. Dr. Wz Johannes Kupang
}

\begin{abstract}
Abstrak
Perdarahan obstetri merupakan penyebab utama kematian maternal dan perinatal.Atonia uteri merupakan penyebab tersering perdarahan postpartum. Perdarahan post partum adalah perdarahan lebih dari $500 \mathrm{cc}$ setelah bayi lahir pervaginam atau lebih dari $1.000 \mathrm{ml}$ setelah persalinan abdominal atau jumlah perdarahan lebih dari normal dan telah menyebabkan perubahan tanda vital. Penyebab atonia uteri adalah overdistensi uterus, kelelahan otot miometrium, plasenta letak rendah, toksin bakteri (korioamnionitis, endomiometritis, septikemia), hipoksia akibat hipoperfusi atau uterus couvelaire pada solusio plasenta dan hipotermia akibat resusitasi masif. Manajemen atonia uteri dapat berupa non farmakologi, farmakologi dan pembedahan menurut algoritma Varatharajan yaitu "HAEMOSTASIS".Manejemen perioperatif atoni uteri terdiri dari terapi $\mathrm{O}_{2}$, monitoring noninvasif, pemasangan jalur intra vena dengan menggunakan kateter intravena yang besar dan resusitasi cairan. Tehnik anestesi tergantung keadaan klinis dan rencana tindakan berikutnya oleh dokter kandungan.Pilihan pertama transfusi darah adalah transfusi sel darah merah, platelet, fresh frozen plasma, kriopresipitat, faktor VII dan fibrinogen sintetis (RiaSTAP), Transfusi masif adalah pemberian transfusi darah sebanyak volume darah pasien dalam waktu 24 jam atau lebih dari $7 \%$ berat badan ideal dewasa. Komplikasi yang dapat terjadi pada transfusi masif adalah hipotermi, hipokalsemia, hipomagnesemia, hiperkalemia, asidosis/ alkalosis, koagulopati dilusional, transfusion related acute lung injury (TRALI)
\end{abstract}

Kata kunci: atonia uteri; manajemen perioperatif atonia uteri; perdarahan postpartum

\section{Perioperative Management in Bleeding cause by Uterine Atony}

\begin{abstract}
Obstetric bleeding is a major cause of maternal and perinatal death. Uterine atony is the most common cause of postpartum hemorrhage. Post partum hemorrhage is bleeding more than $500 \mathrm{cc}$ after the baby is vaginal labor or more than $1,000 \mathrm{ml}$ after abdominal labor or the amount of bleeding is more than normal and has caused changes in vital signs. The causes of uterine atony are uterine overdistence, myometrial muscle fatigue, low lying placenta, bacterial toxin (chorioamnionitis, endomyometritis, septicemia), hypoxia due to hypoperfusion or uterine couvelaire in placental abruption and hypothermia due to massive resuscitation. Management of uterine atony can be in the form of non pharmacology, pharmacology and surgery according to the Varatharajan algorithm is "HAEMOSTASIS". Anesthesia management consists of $\mathrm{O}_{2}$ therapy, noninvasive monitoring, installation of intravenous lines using a large intravenous catheter and fluid resuscitation. Anesthesia techniques depend on clinical conditions and subsequent action plans by the obstetrician. The first choice of blood transfusion is transfusion of red blood cells, platelets, fresh frozen plasma, cryoprecipitate, factor VII and synthetic fibrinogen (RiaSTAP), massive transfusion is the administration of blood transfusion as much as the patient's blood volume within 24 hours or more than $7 \%$ of the ideal adult body weight. Complications that can occur in massive transfusions are hypothermia, hypocalcemia, hypomagnesemia, hyperkalemia, acidosis / alkalosis, dilutional coagulopathy, transfusion related acute lung injury (TRALI).
\end{abstract}

Key words: postpartum hemorrhage; perioperative management uterine atony; uterine atony 


\section{Pendahuluan}

Perdarahan masih menjadi penyebab utama kematian maternal.Angka kematian ibu di Indonesia berdasarkan data Survei Demografi Kesehatan Indonesia (SDKI) tahun 2007 sebesar 228 per 100.000 kelahiran hidup, rasio tersebut sangat tinggi bila dibandingkan dengan negaranegara ASEAN lainnya. Di Indonesia sampai saat ini ada tiga penyebab utama kematian ibu yaitu perdarahan, pre eklampsia-eklampsia, dan infeksi. Perdarahan sebelum, sewaktu, dan sesudah bersalin adalah kelainan yang berbahaya dan mengancam ibu. ${ }^{1,2}$ Perdarahan obstetri merupakan komplikasi serius kehamilan yang dapat menjadi penyebab utama kematian maternal dan perinatal. Plasenta previa, solusio plasenta dan ruptur uteri merupakan penyebab terbanyak perdarahan antepartum, sedangkan atonia uteri merupakan penyebab tersering perdarahan postpartum. ${ }^{1,2}$

Pencegahan dan antisipasi terhadap atonia uteri dapat dilakukan selama periode antenatal. Pada saat pemeriksaan ANC dokter kandungan dapat menentukan apakah seorang wanita hamil termasuk dalam risiko tinggi perdarahan atau tidak. Seorang wanita hamil dapat digolongkan ke dalam risiko tinggi perdarahan post partum apabila terdapat keadaan yang menimbulkan over distensi uterus termasuk kehamilan kembar yang akan dilahirkan pervaginam atau sectio caesarea, riwayat terjadinya perdarahan post partum sebelumnya. Pencegahan yang dilakukan pada wanita hamil dengan risiko seperti tersebut adalah dengan menjaga kadar hemoglobin dan hematokrit dalam batas normal dengan cara pemberian vitamin dan zat besi selama kehamilannya. ${ }^{2-4,9}$ Perdarahan post partum adalah perdarahan lebih dari $500 \mathrm{cc}$ yang terjadi setelah bayi lahir pervaginam atau lebih dari $1.000 \mathrm{ml}$ setelah persalinan abdominal. Kondisi dalam persalinan menyebabkan kesulitan untuk menentukan jumlah perdarahan yang terjadi, maka batasan jumlah perdarahan disebutkan sebagai perdarahan yang lebih dari normal dan telah menyebabkan perubahan tanda vital, antara lain pasien mengeluh lemah, limbung, berkeringat dingin, menggigil, hiperpnea, tekanan darah sistolik $<90 \mathrm{mmHg}$, denyut nadi
$>100 \mathrm{x} /$ menit, kadar $\mathrm{Hb}<8 \mathrm{~g} / \mathrm{dL} .^{2-4,9}$ Perdarahan post partum dapat dibagi menjadi dua yaitu: 1) Perdarahan post partum dini/perdarahan post partum primer (early postpartum hemorrhage) adalah perdarahan yang terjadi dalam 24 jam pertama setelah kala III; 2) Perdarahan pada masa nifas/perdarahan post partum sekunder (late postpartum hemorrhage) adalah perdarahan yang terjadi pada masa nifas (puerperium) tidak termasuk 24 jam pertama setelahkala III. ${ }^{5,6,8-10}$

\section{Pembahasan}

Atonia uteri adalah kegagalan serabut-serabut otot miometrium uterus untuk berkontraksi dan memendek. Atonia uteri merupakan penyebab perdarahan post partum yang paling penting dan biasa terjadi segera setelah bayi lahir hingga 4 jam setelah persalinan. Atonia uteri dapat menyebabkan perdarahan hebat dan dapat mengarah pada terjadinya syok hipovolemik. Kekuatan dan efektifitas kontraksi otot miometrium uterus sangat penting untuk menghentikan perdarahan. Uterus pada atonia uteri akan teraba lunak dan lembut dengan disertai perdarahan aktif dari vagina. ${ }^{3-5,9}$

\section{Etiologi}

Overdistensi uterus, baik absolut maupun relatif, merupakan faktor resiko mayor terjadinya atonia uteri. Overdistensi uterus dapat disebabkan oleh kehamilan ganda, janin makrosomia, polihidramnion atau abnormalitas janin (misal hidrosefalus berat), kelainan struktur uterus atau kegagalan untuk melahirkan plasenta atau

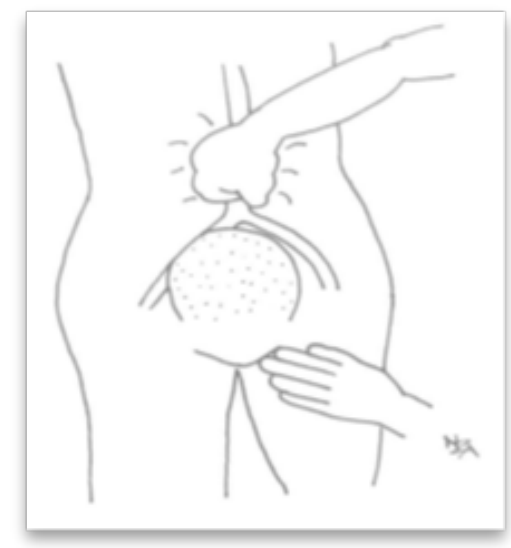

Gambar 1. Kompresi Aorta ${ }^{13}$ 


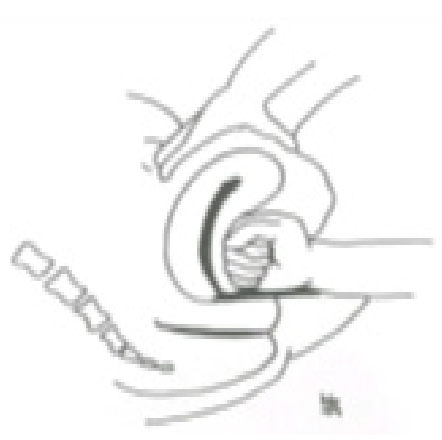

Gambar 2. Kompresi Bimanual ${ }^{13}$

distensi akibat akumulasi darah di uterus baik sebelum maupun sesudah plasenta lahir. ${ }^{4-11}$ Lemahnya kontraksi miometrium merupakan akibat dari kelelahan karena persalinan lama atau persalinan dengan tenaga besar, terutama bila mendapatkan stimulasi. Hal ini dapat pula terjadi sebagai akibat dari inhibisi kontraksi yang disebabkan oleh obat-obatan, seperti nitrat, obatobat antiinflamasi nonsteroid, magnesium sulfat, beta-simpatomimetik, agen anestesi halogen dan nifedipin. Penyebab lain yaitu plasenta letak rendah, toksin bakteri (korioamnionitis, endomiometritis, septikemia), hipoksia akibat hipoperfusi atau uterus couvelaire pada solusio plasenta dan hipotermia akibat resusitasi masif.9-13 Penggunaan oksitosin dalam dosis besar juga dapat menyebabkan atonia uteri. Hasil penelitian menunjukkan bahwa kejadian perdarahan masif post partum sekunder karena atonia uteri lebih tinggi pada wanita yang mendapatkan oksitosin. Juga didapatkan pada pemberian oksitosin yang persisten dapat mengakibatkan desensitisasi reseptor oksitosin sehingga dapat memicu terjadinya atonia uteri. ${ }^{13}$

\section{Manajemen Non Farmakologi/Mekanikal}

Varatharajan melakukan evaluasi terhadap hasil manajemen perdarahan postpartum masif dengan menggunakan algoritma 'HAEMOSTASIS' (Help,Assess and resuscitate,Established diagnosis, Massage of uterus,Oxytocin infusion and prostaglandin,Shift to operation theatre, Tamponade test, Apply compression suture, Systematic pelvic devascularisation, Interventional radiology, and Subtotal/total hysterectomy). Algoritma ini bertujuan untuk memberikan penanganan yang baik terhadap perdarahan post partum sehingga dapat mengurangi transfusi darah, histerektomi dan juga kematian ibu. ${ }^{13}$

\section{Pemijatan uterus (Uterine massage)}

Pemijatan uterus dilakukan dengan cara penggosokan atau stimulasi pada fundus uterus. Terdapat suatu hipotesa bahwa pemijatan dapat mengeluarkan prostaglandin lokal yang dapat menimbulkan kontraktilitas uterus sehingga dapat mengurangi terjadinya perdarahan. Satu penelitian terhadap 200 wanita secara randomized controlled trial didapatkan bahwa pada wanita yang mendapat pemijatan uterus mengalami lebih sedikit perdarahan post partum dan pemberian obat uterotonika lebih sedikit pula dibandingkan dengan wanita yang tidak mendapatkan pemijatan uterus. ${ }^{11-13}$

\section{Kompresi Aorta}

Kompresi aorta dapat membantu mengontrol perdarahan yang terjadi melalui berkurangnya aliran darah pada daerah distal termasuk juga aliran darah pada arteri uterina. Kompresi aorta dilakukan dengan jalan melakukan penekanan pada daerah persendian yang rata diatas kontraksi uterus dan sedikit kearah kiri.Hilangnya pulsasi arteri femoralis merupakan tanda penekanannya sudah benar dan sudah terjadi oklusi aorta secara komplit. Penting untuk diingat bahwa setiap 30 menit harus dilepaskan penekanannya dan dilakukan penekanan ulang lagi dan hal ini dilakukan berulang-ulang dengan tujuan supaya ekstremitas inferior tetap mendapat aliran darah secara intermiten. Kompresi aorta merupakan tindakan intervensi sederhana yang dapat dilakukan sambil mempersiapkan terapi definitif atau selama merujuk pasien. ${ }^{11-13}$

\section{Kompresi bimanual}

Kompresi bimanual dengan cara memasukkan tangan kanan kedalam vagina pada permukaan depan uterus dan tangan kiri di abdomen pada fundus kearah permukaan belakang uterus. Dengan dilakukan penekanan uterus dengan kedua tangan maka hal ini dapat mengurangi perdarahan yang terjadi. Teknik ini dapat dilakukan dengan tujuan untuk melakukan stabilisasi pasien sambil 


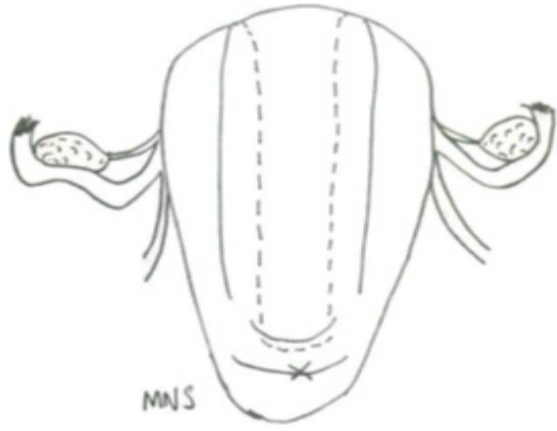

Gambar 3. B-Lynch Suture ${ }^{13}$

mempersiapkan terapi definitif. ${ }^{11-13}$

\section{Tampon uterus}

Pada masa lalu digunakan kasa gulung steril dalam jumlah besar sebagai tampon dalam kavum uterus untuk mengurangi perdarahan masif post partum yang disebabkan atonia uteri. Disamping kurang efektif penggunaan kasa steril sebagai tampon, popularitasnya juga menurun secara drastis seiring dengan penggunaan obat uterotonika secara luas. ${ }^{11-13}$ Saat ini banyak dilakukan penggunaan balon untuk tampon uterus sebagai terapi ajuvan untuk mengurangi perdarahan masif karena atonia uteri. Suatu hipotesa mengatakan bahwa tekanan hidrostatik yang ditimbulkan oleh balon intrauterine pada arteri uterina dapat mengurangi perdarahan yang terjadi. Balon tersebut sering disebut sebagai Bakri balloon, Rusch catheter, SengstakenBlackmore catheter, Foley catheterdan Condom catheter. Bakri balon didesain spesifik sebagai tampon uterus pada perdarahan post partum masif. Bakri balon dilengkapi dengan pipa yng berfungsi sebagai drainase besar untuk keluarnya darah dari kavum uterus.

Walaupun Sengstaken-Blackmore dan Foley kateter memiliki juga saluran sebagai drainase tetapi ukurannya lebih kecil dan cenderung mudah tersumbat oleh bekuan darah. Sebagai tambahan pula bahwa bagian distal kateter Sengstaken-Blackmore dapat menghalangi kontak antara permukaan balon dengan fundus uteri. Dua kateter yang lain (Rusch dan kondom kateter) tidak memiliki saluran drainase dengan

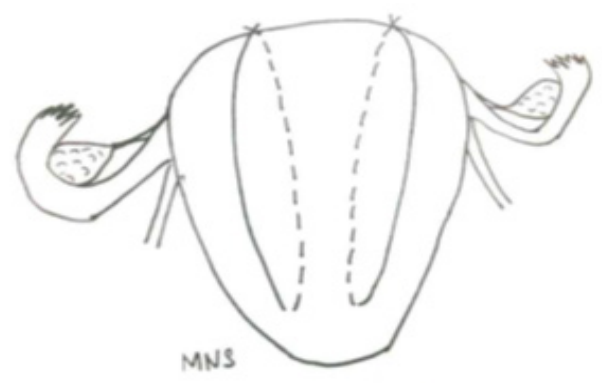

Gambar 4. Hayman Suture ${ }^{13}$

demikian mengakibatkan sulitnya drainase darah dari kavum uteri. ${ }^{11-13}$ Kapasitas pengembangan balon berbeda - beda tergantung dari tipe balon tersebut. Rusch kateter memiliki kapasitas paling

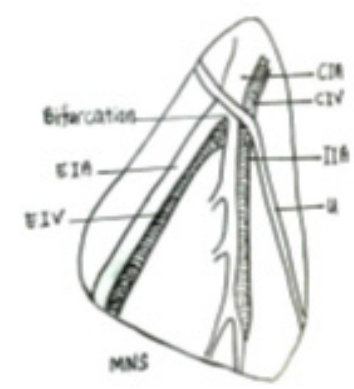

\section{Gambar 5. Ligasi Arteri Hipogastrik}

Keterangan: (EIA: external iliac artery; EIV: external iliac vein; CIA: common iliac artery;CIV: common iliac vein;IIA: internal iliac artery; U: ureter)

besar yaitu $1500 \mathrm{ml}$ cairan, diikuti oleh Bakri balon dengan $500 \mathrm{ml}$ sedangkan SengstakenBlackmore kateter dan kondom kateter dengan kapasitas $300 \mathrm{ml}$. Foleys kateter memiliki kapasitas paling sedikit yaitu $30 \mathrm{ml}$ dan biasanya menggunakan multipel foley kateter. Tes tampon digunakan untuk melihat keberhasilan mengontrol perdarahan karena atonia uteri. Jika tes tampon menunjukkan hasil negative ini merupakan indikasi kegagalan mengontrol perdarahan sehingga diperlukan terapi tambahan seperti compressive sutures, devaskularisasi pelvis sistemik atau histerektomi. ${ }^{11-13}$ Efek samping penggunaan balon sejauh ini akibat dari overdistensi balon yaitu nekrosis karena tekanan dan rupture uteri. Komplikasi lain yang dapat 
terjadi adalah perforasi uterus dan emboli udara apabila digunakan udara untuk mengembangkan balon; untuk itu tidak direkomendasikan mengembangkan balon menggunakan udara. Karena atonia uteri merupakan penyebab terbanyak dari perdarahan post partum, maka disarankan penggunaan tampon balon uteri selama merujuk pasien untuk mengurangi morbiditas dan mortalitas. ${ }^{11-13}$

\section{Manajemen Bedah}

Pada kebanyakan kasus, manajemen non farmakologi dan uterotonika dapat mengurangi perdarahan masif karena atonia uteri.Jika tidak menunjukkan respon yang baik maka perlu dilakukan tindakan pembedahan.

\section{B-LynchSuture}

Pada atonia uteri, pembuluh darah terutama pada tempat melekatnya plasenta (placental bed) tidak mampu berkontraksi untuk mengurangi perdarahan. B-Lynch suture dilaporkan untuk pertama kalinya pada tahun 1997 , terdiri dari jahitan vertikal untuk kompresi pada sistem vaskular uterus. Dilaporkan bahwa angka keberhasilannya 91,7\%. Tindakan ini sederhana, cepat dan merupakan tindakan penyelamatan untuk mengatasi perdarahan dari atonia uteri.Sebelum tindakan ini dilakukan, untuk memprediksi keberhasilan tindakan ini maka dilakukan terlebih dahulu kompresi uterus secara manual.Tangan kiri dokter bedah diletakkan pada bagian belakang uterus sementara tangan kanannya menekan segmen bawah uterus. Jika terjadi pengurangan jumlah darah yang keluar maka kompresi dengan jahitan ini kemungkinan besar efektif. ${ }^{11-13}$ Posisi Lloyd-Davis lebih disukai saat dilakukan prosedur penanganan terhadap perdarahan pervaginam dan ini dilakukan secara simultan. B-Lynch Suture menggunakan benang yang dapat diserap dengan jarum bulat.BLynch Suture teknik ini relatif aman dan tidak mempengaruhi fertilitas. ${ }^{11-13}$

\section{Hayman Suture}

Hayman suture kompresi terhadap uterus merupakan metode lain untuk menghentikan perdarahan karena atonia uteri. Teknik ini tidak memerlukan insisi pada segmen bawah rahim sehingga merupakan pilihan yang baik ketika perdarahan post partum terjadi saat persalinan pervaginam. Tindakan lebih cepat, lebih mudah dan kurang traumatik terhadap uterus. Angka keberhasilan teknik ini sekitar 93,75\%. Akan tetapi kemungkina bisa mengakibatkan terjebaknya darah dalam kavum uteri sehingga dapat menimbulkan terjadinya hematometra, piometra dan nekrosis uterus. ${ }^{11-13}$

\section{Ligasi Arteri Uterina Bilateral}

Teknik ini lebih muudah dengan lebih sedikit komplikasi yang dilaporkan pertama kali oleh Waters tahun 1952. Tindakan ini termasuk pendekatan melalui abdomen bagian bawah seperti insisi Pfanenstiel.Uterus dikeluarkan dan ditarik keatas untuk identifikasi pembuluh darah uterus.Benang yang dapat diabsorbsi ditempatkan $2 \mathrm{~cm}$ dibawah vesika urinaria pada kedua sisi uterus dan harus dihindari ureter. Pada teknik ini dilakukan oklusi pada cabang pembuluh darah uterus bagian atas dengan angka keberhasilan 80\%-96\%. Teknik ini aman untuk kejadian trauma pada ureter. ${ }^{11,13}$

\section{Ligasi Arteri Hipogastrik Bilateral}

Teknik ini merupakan teknik paliing tua yang telah diperkenalkan pada awal tahun 1960. Diperlukan pengetahuan anatomi yang baik untuk menghindari trauma yang tidak disengaja pada pembuluh darah iliaka dan ureter.Angka keberhasilan ligasi arteri hipogastrik bervariasi antara $42-93 \%$. Ligasi yang tidak tepat dapat mengakibatkan iskemi ekstremitas inferior, nyeri pada bagian pantat, perdarahan akan berlanjut dan kemungkinan trauma pada ureter dan saraf.

\section{Embolisasi}

Embolisasi arteri uterina merupakan suatu teknologi yang baru dalam penanganan perdarahan post partum. Hal ini hanya terdapat di rumah sakit pusat rujukan dan memerlukan juga intervensi radiologis dengan didampingi dokter kandungan. Pada prosedur ini diperlukan hemodinamik yang stabil ${ }^{11-13}$ Pada umumnya perdarahan post partum yang disebabkan atonia uteri sering tidak dapat diprediksi dan terjadi dalam waktu singkat. Dalam keadaan seperti ini 
penggunaan balon sebagai tampon uterus dapat mengurangi sebagian perdarahan, pada saat yang bersamaan dapat dilakukan embolisasi arteri uterina, hal ini memungkinkan menghindari histerektomi sehingga tetap dapat menjaga fertilitas. Angka keberhasilan embolisasi arteri uterine berkisar $70-100 \%$.Karena vaskularisasi pada daerah pelvis sangat banyak anastomosis maka diperlukan embolisasi arteri uterina bilateral untuk menjamin keberhasilan tindakan ini. Komplikasi yang mungkin dapat terjadi termasuk karena kegagalan embolisasi adalah tetap terjadinya perdarahan, infeksi, trauma pada pembuluh darah, nyeri post operasi dan panas. ${ }^{11-13}$

\section{Histerektomi}

Histerektom peripartum karena perdarahan post partum merupakan keputusan yang sulit untuk dibuat tetapi harus dilakukan sebagai prosedur penyelamatan jiwa. Walaupun pada umumnya merupakan pilhan terakhir akan tetapi pada kasus - kasus tertentu dapat menjadikan pilihan pertama ketika fertilitas tidak lagi dibutuhkan. Insidennya bervariasi diatas 8 per 1000 kelahiran, sedangkan morbiditas dari peripartum histerektomi adalah sebesar $30-40 \%$. Komplikasi yang dapat terjadi teramsuk trauma pada ureter dan vesika urinaria, perdarahan tetap berlangsung sehingga diperlukan eksplorasi ulang, pneumonia dan fistel urinaria. Peri partum histerektomi dapat dikerjakan baik total atau subtotal histerektomi. Pada total histerektomi dapat mengurangi terjadinya kanker serviks tetapi diperlukan waktu operasi lebih lama dan risiko lebih tinggi terjadinya trauma pada traktus urinarius. Sedangkan pada subtotal histerektomi lebih cepat waktu operasinya tetapi tetap diperlukan skrining terhadap kanker serviks. ${ }^{11-13}$

\section{Manajemen Anestesi}

Penatalaksanaan anestesi awal terhadap perdarahan post partum terdiri dari intervensi dasar termasuk didalamnya terapi $\mathrm{O}_{2}$, monitoring noninvasif, pemasangan jalur intra vena dengan menggunakan kateter intravena yang besar dan melakukan resusitasi cairan. Penilaian klinis perdarahan post partum harus dilakukan secara simultan dengan resusitasi cairan. Pada saat yang bersamaan dokter kandungan harus melakukan tindakan awal dengan kompresi bimanual uterusdan pemijatan uterus sambil mencoba mencari penyebab utama terjadinya perdarahan post partum; apakah penyebabnya karena atonia uteri, retensio plasenta, robekan jalan lahir atau gangguan koagulasi (koagulopati). Pemilihan tehnik anestesi tergantung dari keadaan klinis dan rencana tindakan berikutnya oleh dokter kandungan. Perlu diingat jika terjadi keterlambatan pada intervensi awal maka akan berakibat kehilangan darah lebih banyak sehingga perlu dipertimbangkan untuk

Tabel 1. Obat-obatan Atonia Uteri ${ }^{13}$

\begin{tabular}{lcc}
\hline \multicolumn{1}{c}{ Drug } & \multicolumn{1}{c}{ Dosage and route } & Considerations \\
\hline FIRST-LINE & & \\
Oxytocin & $\begin{array}{l}10-40 \mathrm{U} / \mathrm{L} \text { of saline or lactated Ringer } \\
\text { solution, infused continuously,OR 10 U IM }\end{array}$ & The preferred drug-often the only one needed \\
& &
\end{tabular}

\section{SECOND-LINE}

Misoprosto (Cytotec, ProstaglandinE1)

Methylergonovine (Methergine)

Carboprost tromethamine (Hemabate)

Dinoprostone (Prostin E2)
$800-1,000 \mu \mathrm{g}$ can be given rectally

$0.2 \mathrm{mg}$ IM every $2-4 \mathrm{hr}$

$0.25 \mathrm{mg}$ IM every $15-90$ minutes (maximum of 8 doses)

$20 \mathrm{mg}$ suppository can be given vaginally or rectally every 2 hours
Often, the second-line drug that is given just after oxytocin because it is easy to administer

Contraindicated in hypertension

Avoid in patients who have asthma.

Contraindicated in hepatic, renal, and cardiac disease

Avoid in hypotension 
menguasai jalan nafas dengan segera. , $3,11-13^{-13}$

\section{Obat - Obatan Untuk Atonia Uteri}

Oksitosin

Saat ini oksitosin merupakan obat pertama yang sering digunakan untuk pencegahan maupun pengobatan atonia uteri. Walaupun demikian dosis dan cara pemberiannya sangat bervariasi dan tidak ada pedoman yang benar tentang cara pemberian dan dosis yang efektif. Dalam praktek sehari-hari sering digunakan bolus intravena 5-10 unit. Walaupun demikian efek samping yang timbul tergantung dari dosis pemberian dan biasanya tidak akan muncul bila pemberiannya dilarutkan dengan cairan intravena. Beberapa ahli menyarankan supaya tidak memberikan bolus oksitosin lebih dari 5 unit, akan tetapi masih sedikit penelitian yang dilakukan terhadap cara paling efektif dalam pemberian oksitosin. Penelitian terbaru menemukan bahwa pemberian oksitosin secara bolus dengan dosis 0,35 unit yang dilanjutkan dengan pemberian $40 \mathrm{mU} /$ menit sangat efektif untuk menjaga kontraksi uterus pada pasien sectio caesarea elektif. Hal sebaliknya terjadi pada pasien yang menjalani operasi sectio caesarea akan mengalami perpanjangan kelemahan kontraksi uterus bila sudah dilakukan induksi persalinan dengan oksitosin sebelumnya, dan didapatkan dosis minimum efektif 2,99 unit.Pada umumnya untuk profilaksis bisa diberikan oksitosin 20 unit yang dilarutkan dalam 1 liter cairan intravena. Pada saat terjadi atonia uteri dapat ditambahkan 20 unit lagi dalam 1 liter cairan intravena dan diberikan dosis kecil 0,5-1 unit untuk bolus. ${ }^{7,8,12,14}$ Aspek penting tentang pemberian oksitosin secara invitro menunjukkan bahwa pemberian oksitosin secara kontinyu mengakibatkan penurunan respon sel myometrium terhadap oksitosin. Hal ini terjadi karena desensitisasi atau penurunan respon dari reseptor oksitosin.Hal ini bisa merubah pandangan bahwa pemberian oksitosin dosis tinggi pada perpanjangan fase persalinan adalah tidak memberikan keuntungan. Oleh karena itu perlu dipertimbangkan sejak awal untuk memberikan obat uterotonika lain pada kasus atonia uteri dengan perdarahan hebat. Efek samping yang sering timbul dari pemberian oksitosin bolus intravena adalah mual, muntah dan
hipotensi.Penurunan tekanan darah ini bersifat sementara, biasanya disertai dengan takhikardi sebagai kompensasi untuk meningkatkan kardiak output.Karena hipotensi ini bersifat sementara maka pada umumnya masih bisa ditoleransi oleh pasien-pasien obstetrik.Peningkatan frekwensi jantung atau kardiak output sangat berbahaya pada pasien dengan gangguan jantung sebelumnya sehingga diperlukan perhatian khusus. Perhatian khusus juga diperlukan terhadap pasien yang mengalami syok hipovolemik. ${ }^{11-15}$

\section{Ergonovin Maleat}

Ergot merupakan obat pilihan kedua untuk penanganan atonia uteri.Ergot meningkatkan tonus uterus melalui stimulasi secara langsung reseptor alfa adrenergik. Pada umumnya diberikan dengan dosis $0,25 \mathrm{mg}$ secara intramuskuler tetapi dapat juga diberikan dengan dosis 0,125 mg secara intravena.Jika diberikan terlalu cepat dapat mengakibatkan mual, muntah hebat dan hipertensi berat.Onset dari ergot adalah 3-5 menit. Kadang-kadang ergot diberikan pada bahu bagian depan, hal ini berbeda dengan cara pemberian oksitosin. Ergot tidak boleh diberikan sebelum plasenta dilahirkan, karena dapat menyebabkan peningkatan insiden retensio plasenta. Ergot alkaloid dapat menyebabkan konstriksi arteri dan vena. Hal ini dapat menimbulkan efek kardiovaskuler yang sangat signifikan, khususnya hipertensi dan spasme arteri koronaria. Efek ini tampak semakin jelas pada pasien hipertensi dalam kehamilan, hipertensi kronis dan jika dikombinasi dengan vasopresor yang lain. Apabila terjadi peningkatan tekanan darah secara tiba -tiba, maka dapat diberikan pengobatan dengan vasodilator seperti nitrogliserin, nitroprusid atau hidralazin. ${ }^{11-15}$

\section{Karboprost (Hemabate)}

Karboprost (15-Methyl Prostaglandin F2 alpha) pada umumnya diberikan secara injeksi intra miometrial tetapi dapat juga diberikan secara intramuskuler. Dosis awal dapat diberikan 0,25 $\mathrm{mg}$ dan dapat diulang setiap 15 menit sampai mencapai dosis maksimal $2 \mathrm{mg} / 24$ jam. Efek samping yang dapat terjadi adalah vasokonstriksi perifir akut, hipertensi,terutama pada pasien hipertensi dalam kehamilan, bronkhokonstriksi, 
gangguan ventilasi dan perfusi yang dapat menyebabkan hipoksemia. Karboprost juga tidak boleh diberikan pada pasien dengan penurunan fungsi paru, terutama asma berat dan bronkhitis kronis. ${ }^{11-15}$

\section{Misoprostol}

Misoprostol merupakan analog prostaglandin E2 sintetis dan diberikan dengan dosis 1000 mcg per rectum.Pada keadaan atonia uteri, dapat diberikan misoprostol dan karboprost secara simultan karena kedua obat tersebut bekerja pada reseptor yang berbeda. Misoprostol cenderung menyebabkan vasodilatasi sehingga dapat mengakibatkan hipotensi. Penurunan SVR biasanya akan diikuti oleh peningkatan frekwensi jantung dan kardiak output. ${ }^{11-15}$

\section{Terapi Cairan}

Sebagai tindakan awal resusitasi cairan adalah dengan cara pemberian cairan intravena secara cepat. Tujuannya adalah memperbaiki aliran darah mikrovaskuler dengan maksud untuk mempertahankan oksigenasi jaringan melalui cara meningkatkan volume intravaskuler dan kardiak output. Jenis cairan yang digunakan dan jumlah cairan yang diberikan tergantung dari penyebab yang mendasari insufisiensi sirkulasi dan cairan yang tersedia. Pemilihan antara kristaloid dengan koloid untuk resusitasi cairan masih merupakan suatu perdebatan. Pemberian cairan normal salin dalam jumlah besar telah dilaporkan dapat mengakibatkan keadaan asidosis hiperkloremik. Karena komposisisi ringer laktat yang menyerupai dengan komposisi plasma sehingga cairan ini merupakan cairan kristaloid fisiologis yang banyak tersedia dan sering digunakan. Berbeda dengan kristaloid, cairan koloid dapat bertahan lebih lama di intravaskuler sehingga hal ini sangat efektif diberikan pada pasien dengan hipovolemia yang berat. Setelah dilakukan pemberian cairan intravena awal baik itu cairan koloid sebanyak $10 \mathrm{ml} / \mathrm{kgbb}$ ataupun cairan kristaloid sebanyak $20 \mathrm{ml} / \mathrm{kgbb}$ kemudian harus dievaluasi keadaan klinis dan respon hemodinamik. ${ }^{2-4,12,13}$ Pemberian cairan intravena awal dapat diulangi jika pasien masih dalam keadaan hipovolemik. Cairan kristaloid diberikan sebanyak lebih kurang tiga kali dari jumlah darah yang hilang, tetapi untuk cairan koloid diberikan sama dengan jumlah darah yang hilang. Pemberian cairan intravena sebanyak itu dilakukan sambil menunggu ketersediaan darah melalui crossmatched. Koagulopati merupakan suatu akibat dari kehilangan darah masif atau transfusi darah masif. Koreksi hipotermi merupakan salah satu cara mencegah terjadinya koagulopati. Asidosis yang berat dapat dikoreksi dengan pemberian natrium bikarbonat, hal ini untuk mencegah terjadinya depresi miokard karena asidosis yang tidak dapat dikoreksi dengan cara pemberian ventilasi. $^{2-4,12-15}$

\section{Transfusi Sel Darah Merah}

Pada pasien atonia uteri yang mengalami perdarahan hebat pilihan pertama untuk transfusi darah adalah transfusi sel darah merah.Setiap unit sel darah merah dapat meningkatkan hematokrit 3 $\%$ dan hemoglobin sebesar $1 \mathrm{~g} / \mathrm{dL}$, dengan asumsi bahwa perdarahan sudah terkendali. Setelah itu dapat dipertimbangkan pemberian: ${ }^{11-15}$

\section{Platelet}

Pemberian platelet tergantung dari beratnya perdarahan dan jumlah platelet. Pemberian $50 \mathrm{ml}$ unit dapat meningkatkan jumlah platelet 5.000 $10.000 / \mathrm{mm} 3$. Pemberian platelet dipertimbangkan jika jumlah platelet dibawah $50.000 / \mathrm{mm} 3 .^{12-15}$

\section{Fresh Frozen Plasma}

Fresh frozen plasma diberikan dengan tujuan untuk mengganti faktor-faktor pembekuan. Fresh frozen plasma mengandung semua faktor koagulasi kecuali trombosit. Setiap unit fresh frozen plasma dapat meningkatkan kadar fibrinogen sebesar $10 \mathrm{mg} / \mathrm{dl}$. Pemberian fresh frozen plasma diindikasikan pada perdarahan post partum dengan tujuan untuk mengatasi koagulopati baik karena dilusi ataupun pada keadaan-keadaan yang mengakibatkan hilangnya faktor-faktor pembekuan seperti pada abortus dengan perdarahan masif, emboli air ketuban, preeklamsia berat dan iufd dengan janin yang lama dalam kandungan. ${ }^{12-15}$

Kriopresipitat

Kriopresipitat mengandung fibrinogen, faktor VIII, faktor XIII dan faktor von Willebrand. 
Setiap unit kriopresipitat dapat meningkatkan level fibrinogen sebesar $10 \mathrm{mg} / \mathrm{dl}$. Kriopresipitat mengandung sangat banyak faktor-faktor pembekuan darah walaupun dalam volume yang sedikit. Kandungan fibrinogen dalam kriopresipitat lebih kurang dua kali lipat daripada fresh frozen plasma. ${ }^{12-15}$

\section{Faktor VII}

Faktor VII dapat diberikan jika perdarahan tetap aktif, tetapi harus diberikan setelah pemberian fresh frozen plasma dan kriopresipitat untuk mengganti faktor pembekuan darah, karena faktor VII tidak efektif tanpa pemberian faktor pembekuan terlebih dahulu. Pemberian faktor VII mempunyai risiko tinggi untuk terjadinya tromboemboli dan juga harganya mahal. ${ }^{12-14}$

Fibrinogen sintetis (RiaSTAP)

Hanya tersedia di Amerika Serikat, tetapi FDA merekomendasikan pemberian fibrinogen sintetis hanya ditujukan untuk pasien dengan perdarahan akut yang memiliki defisiensi fibrinogen kongenital. Hal ini mungkin sangat bermanfaat diberikan pada pasien perdarahan post partum oleh karena atonia uteri dengan kekurangan faktor pembekuan esensial. ${ }^{12,14}$

\section{Transfusi Masif}

Pada pasien dengan perdarahan oleh karena atonia uteri pada umumnya diperlukan transfusi darah dalam jumlah besar. Yang dimaksud dengan transfusi masif adalah pemberian transfusi darah sebanyak volume darah pasien dalam waktu 24 jam atau lebih dari $7 \%$ berat badan ideal dewasa. Transfusi masif dapat juga didefinisikan sebagai pemberian transfusi darah sebanyak $50 \%$ dari volume darah pasien dalam waktu kurang dari 3 jam atau pemberian 4 unit PRC dalam waktu satu jam dan diperkirakan masih diperlukan transfusi lebih banyak lagi. ${ }^{11,12,14,16}$

Pada transfusi masif diperlukan pemeriksaan laboratorium untuk menghindari komplikasi yang tidak diinginkan. Pemeriksaan laboratorium yang diperlukan adalah hematokrit, trombosit, international normalized ratio (INR), activated partial thromboplastin time (APTT) dan fibrinogen. Berdasarkan pedoman American
Society Anesthesiologist (ASA) mengenai transfusi masif adalah pemberian cairan awal adalah kristaloid dan koloid yang kemudian diikuti dengan transfusi sel darah merah. FFP hanya diberikan apabila seluruh volume darah atau lebih telah diberikan. Sedangkan pemberian transfusi platelet hanya diberikan apabila terdapat perdarahan mikrovaskular akibat koagulopati dan bila trombositopenia diperkirakan terjadi. ${ }^{11,12,14,16}$ Komplikasi yang dapat terjadi pada transfusi masif adalah:

\section{Hipotermi}

Pencegahan terjadinya hipotermi pada transfusi masif dapat mengurangi angka morbiditas dan mortalitas secara signifikan. Pada umumnya komplikasi yang terjadi pada transfusi masif erat hubungannya dengan penurunan suhu tubuh. Aritmia dan perubahan EKG dapat terjadi apabila darah masih dalam keadaan dingin ditransfusikan melalui vena sentral. Depresi miokard merupakan penyebab utama terjadinya hipotensi dan penurunan kardiak output dan saat bersamaan terjadi peningkatan afinitas hemoglobin terhadap oksigen. Perubahan ini sangat merugikan pasien yang sudah mengalami hipovolemi dan kemungkianan dalam keadaan syok. Bahkan juga terjadi penurunan platelet dan fungsi koagulasi karena hipotermi tersebut. Sehungga dengan demikian sangat penting untuk menjaga kondisi suhu tubuh pasien selama mendapatkan transfusi masif. ${ }^{11-16}$

\section{Metabolik}

Hipokalsemia

Sitrat yang digunakan sebagai antikoagulan pada produk darah bersifat mengikat kalsium sehingga dapat menyebabkan hipokalsemia, yang ditandai dengan gejala umum adalah hipotensi. Arotmia dan depresi miokard dapat menyebabkan gangguan hemodinamik lebih lanjut. ${ }^{11,13,14}$ Pengobatan tidak hanya berdasarkan kadar kalsium total tetapi berdasarkan kadar ion kalsium yang merupakan bentuk aktifion kalsium. Biasanya $\mathrm{CaCl}$ lebih disukai dibandingkan kalsium glukonat. Satu gram kalsium klorida umumnya diberikan dengan kecepatan $100 \mathrm{mg} /$ menit. Pada saat dilakukan pemberian kalsium klorida diperlukan monitoring ketat serum ion kalsium. ${ }^{11,13-16}$ Hipomagnesemia 
Hipomagnesemia juga merupakan komplikasi dari keracunan sitrat dan angka kejadiannya meningkat pada saat hipotermi. Kadar magnesium yang rendah merupakan penyebab terjadinya fibrilasi ventrikel refrakter dan dapat memperburuk keadaan hipokalemia. Indikasi pengobatan dengan kadar magnesium kurang dari $1 \mathrm{meq} / \mathrm{l}(0,5 \mathrm{mmol} / \mathrm{l})$ atau tergantung dari gejala klinis yang tampak. ${ }^{11,13-16}$ Magnesium sulfat dapat dilarutkan dengan $10 \mathrm{ml} \mathrm{D5 \%} \mathrm{dan} \mathrm{dalam}$ keadaan emergensi dapat diberikan lebih dari 1-2 menit. Sebaiknya diberikan secara perlahan lebih kurang selama 10 menit untuk mengurangi efek samping yang terjadi termasuk hipotensi (karena vasodilatasi) dan bradikardi. ${ }^{11,13-16}$

\section{Hiperkalemia}

Kalium dilepaskan secara perlahan dari sel darah merah yang disimpan yang dapat merupakan penyebab terjadinya 5\% hyperkalemia pada transfusi masif.Sel darah merah yang disimpan selama 28 hari dapat menyebabkan pelepasan kalium sebesar $6 \mathrm{mmol}$ per unit sel darah merah. Peningkatan gelombang $\mathrm{T}$ dapat diterapi dengan menggunakan kalsium klorida intravena. ${ }^{11,13,14}$

\section{Asidosis/Alkalosis}

Adanya zat tambahan pada sel darah merah yang disimpan mengakibatkan penurunan $\mathrm{pH}$ kurang dari 7,0. Setelah disimpan 21 hari akan terjadi penurunan $\mathrm{pH}$ sampai 6,9 sebagai akibat sekunder akumulasi laktat dan asam piruvat sebanyak $\mathrm{CO}_{2}$ hasil dari metabolism sel darah merah. Walaupun peningkatan $\mathrm{CO}_{2}$ dapat diatasi dengan ventilasi adekuat tetapi asidosis metabolic mungkin tetap dapat terjadi. Meskipun demikian patut dicatat bahwa respon keseimbangan asam basa sangat bervariasi seperti pada metabolism sitrat untuk menghasilkan HCO yang kemungkinan besar dapat meningkatkan $\mathrm{pH} .{ }^{11,13,14,15}$

Oleh sebab itu terapi empiris tidak dianjurkan dan pengobatan harus berdasarkan analisa gas darah. Jika kondisi pasien berkembang menjadi asidosis metabolik dapat diberikan HCO31 meq/ $\mathrm{kg}$, kemudian dilihat respon pasien, pemberian ini dapat diulang setiap 10 menit dengan dosis $0,5 \mathrm{meq} / \mathrm{kg}$. Pada umumnya asidosis metabolik ringan ditoleransi dengan baik. Pemberian $\mathrm{HCO}_{3}$ harus sudah dipikirkan ketika base excess lebih dari $7 \mathrm{meq} / 1 .{ }^{11,13-15}$

\section{Koagulopati dilusional}

Penelitian menunjukkan lebih dari 50\% pasien yang mendapat transfusi masif dapat berkembang menjadi koagulasi dilusional yang ditandai dengan peningkatan INR lebih dari 0,2; dimana $33 \%$ dengan jumlah trombosit kurang dari 50.000. Koagulopati delusional merupakan keadaan lebih lanjut dari disseminated intravascular coagulopathy (DIC), seperti yang terjadi pada solusio plasenta berat, kematian bayi intra uterin yang lama dan emboli air ketuban. ${ }^{11,14-16}$ Selama transfusi masif dilakukan dan keadaan klinis koagulopati dengan trombositopenia kurang dari 75.000/mm3 maka akan dilakukan pengelolaan dengan memberikan trombosit konsentrat (TC). Pengelolaan harus berdasarkan hasil pemeriksaan laboratorium yang disertai keadaan klinis pasien. ${ }^{11,14,15}$ Hipofibrinogenemia merupakan tanda adanya koagulopati paling awal pada transfusi masif. Nilai fibrinogen dipertahankan $\geq 1 \mathrm{~g} / 1$ dengan menggunakan FFP atau dapat juga dengan pemberian kriopresipitat jika terjadi keadaan overhidrasi. Akan tetapi padasebagian besar kasus perdarahan post partum yang dilakukan resusitasi cairan, terutama pada awal resusitasi. Oleh karena itu FFP merupakan pilihan terbaik karena setiap unit FFP mengandung dua kali jumlah fibrinogen jika dibandingkan dengan kriopresipitat. ${ }^{11,14,15}$ Meskipun faktor V dan VIII merupakan faktor yang labil pada darah simpan, tetapi mereka jarang menjadi penyebab perdarahan sekunder pada transfusi masif. Hal ini disebakan karena kadar faktor $\mathrm{V}$ dan faktor VIII yang kurang 30\% dari normal masih cukup adekuat untuk fungsi hemostasis. ${ }^{11,14,15}$ Perlu ditambahkan pada pasien hipotermi dapat mengakibatkan perdarahan yang bermakna secara klinis walaupun sudah dilakukan transfusi darah, plasma dan trombosit. Dengan demikian harus dihindari keadaan hipotermi pada saat dilakukan koreksi terhadap gangguan koagulopati. 11,14,15 $^{15}$

Transfusion Related Acute Lung Injury (TRALI) Kasus ini umumnya behubungan erat dengan transfusi sel darah merah, trombosit dan plasma tetapi dapat pula terjadi dengan transfuse produk 
darah yang lain seperti gama globulin. Sindrom ini terdiri dari distres saluran pernafasan bagian atas, hipoksemia, hipotensi, panas dan udem kedua paru-paru. Udem paru ini murni berasal dari nonkardiak, hal ini menyebabkan tekanan yang rendah pada udem paru dan secara klinis tidak berbeda dengan ARDS. ${ }^{14-16}$ Pada keadaan yang ringan pasien akan tetap hidup dan mungkin menunjukkan gejala hipoksia yang yang bersifat sementara. Oleh karena itu mungkin dapat menjadi diagnosis banding hipoksemia dan atau udem paru pada pasien yang mendapatkan transfusi darah. ${ }^{14-16}$ TRALI umumnya terjadi pada 2 jam pertama transfusi tetapi pernah dilaporkan terjadi TRALI setelah 6 jam transfusi.Seringkali terjadi perbaikan dalam waktu 24-72 jam dengan terapi suportif termasuk menggunakan ventilasi mekanik. Kematian karena TRALI dapat diturunkan lebih dari $10 \%$ dan pada kenyataannya merupakan penyebab kematian terbesar ketiga yang berhubungan dengan transfusi. ${ }^{14-16}$

\section{Simpulan}

Perdarahan masih menjadi penyebab utama kematian maternal. Angka Kematian Ibu (AKI) di Indonesia berdasarkan data Survei Demografi Kesehatan Indonesia (SDKI) tahun 2007 sebesar 228 per 100.000 kelahiran hidup. Perdarahan obstetri merupakan komplikasi serius kehamilan yang dapat menjadi penyebab utama kematian maternal dan perinatal. Pencegahan dan antisipasi terhadap atonia uteri dapat dilakukan selama periode antenatal. Pencegahan yang dilakukan pada wanita hamil dengan risiko tinggi adalah dengan cara pemberian vitamin dan zat besi selama kehamilannya. Perdarahan post partum adalah perdarahan lebih dari $500 \mathrm{cc}$ yang terjadi setelah bayi lahir pervaginam atau lebih dari 1.000 $\mathrm{ml}$ setelah persalinan abdominal. Perdarahan post partum dapat dibagi menjadi dua yaitu perdarahan post partum dini/perdarahan post partum primer (early postpartum hemorrhage) dan perdarahan pada masa nifas / perdarahan post partum sekunder (late postpartum hemorrhage). Atonia uteri adalah kegagalan serabut-serabut otot miometrium uterus untuk berkontraksi dan memendek. Atonia uteri merupakan penyebab perdarahan post partum yang paling penting dan biasa terjadi segera setelah bayi lahir hingga 4 jam setelah persalinan. Penyebab atonia uteri adalah overdistensi uterus, lemahnya kontraksi miometrium akibat dari kelelahan karena persalinan lama atau persalinan dengan tenaga besar, inhibisi kontraksi yang disebabkan oleh obat-obatan, plasenta letak rendah, toksin bakteri (korioamnionitis, endomiometritis, septikemia), hipoksia akibat hipoperfusi atau uterus couvelaire pada solusio plasenta dan hipotermia akibat resusitasi masif. Pada kebanyakan kasus, manajemen non farmakologi dan uterotonika dapat mengurangi perdarahan masif karena atonia uteri. Jika tidak menunjukkan respon yang baik maka perlu dilakukan tindakan pembedahan. Menurut algoritma Varatharajan manajemen perdarahan post partum masif menggunakan 'HAEMOSTASIS'.

Penatalaksanaan anestesi awal terhadap perdarahan post partum terdiri dari intervensi dasar termasuk didalamnya terapi $\mathrm{O}_{2}$, monitoring noninvasif, pemasangan jalur intra vena dengan menggunakan kateter intravena yang besar dan melakukan resusitasi cairan.Pemilihan tehnik anestesi tergantung dari keadaan klinis dan rencana tindakan berikutnya oleh dokter kandungan. Oksitosin merupakan obat pertama yang sering digunakan untuk pencegahan maupun pengobatan atonia uteri.Efek samping yang sering timbul dari pemberian oksitosin bolus intravena adalah mual, muntah dan hipotensi. Ergot, karboprost (15-Methyl Prostaglandin F2 alpha) dan misoprostol merupakan obat pilihan kedua untuk penanganan atonia uteri. Pada pasien atonia uteri yang mengalami perdarahan hebat pilihan pertama untuk transfusi darah adalah transfusi sel darah merah, setelah itu dapat diberikan platelet, fresh frozen plasma, kriopresipitat, faktor VII dan fibrinogen sintetis (RiaSTAP), Transfusi masif adalah pemberian transfusi darah sebanyak volume darah pasien dalam waktu 24 jam atau lebih dari $7 \%$ berat badan ideal dewasa. Pemeriksaan laboratorium yang diperlukan adalah hematokrit, trombosit, international normalized ratio (INR), activated partial thromboplastin time (APTT) dan fibrinogen. Berdasarkan pedoman American Society Anesthesiologist (ASA) mengenai transfusi masif adalah pemberian cairan awal 
kristaloid dan koloid kemudian diikuti dengan transfusi sel darah merah. FFP hanya diberikan apabila seluruh volume darah atau lebih telah diberikan. Sedangkan platelet hanya diberikan apabila terdapat perdarahan mikrovaskular akibat koagulopati dan bila trombositopenia diperkirakan terjadi. Komplikasi yang dapat terjadi pada transfusi masif adalah hipotermi, hipokalsemia, hipomagnesemia, hiperkalemia, asidosis/alkalosis, koagulopati dilusional, transfusion related acute lung injury (TRALI).

\section{Daftar Pustaka}

1. Saifuddin AB, Adriaansz G, Wiknjosastro GH, Waspodo D. Buku Acuan Nasional Pelayanan Kesehatan Maternal dan Neonatal, Jakarta:JNPKKR-YBPSP, 2000.

2. Bisri T, Suwondo BS, Wahjoeningsih S. Anestesi Obstetri. Komisi Pendidikan SpAn KAO,KATI. 2013, 153-64.

3. Chestnut DH. Obstetric anesthesia: Principles and practice. 4th edition. Mosby Elsheiver. Philadelphia. 2009, 811-36.

4. Hughes CS. Anesthesia For Obstetrics. 4thedition. Lippincot William \& Wilkins. Philadelphia, 361-371.

5. Prawirohardjo S. Ilmu Kandungan. Yayasan Bina Pustaka Sarwono Prawirohardjo. Jakarta. 2005.

6. Porter M. Obstetric Anaesthetists Handbook. 7thedition. University Hospitals Coventry and Warwickshire NHS Trust.2013.

7. Braveman FR. $1^{\text {st }}$ ed. Obstetric and gynecologic anesthesia. Mosby Elsheiver. Philadelphia. 2006.

8. Evensen A, Anderson J. Advanced Life
Support in Obstetric (ALSO) and post partum hemorrhage. Chapter J Post Partum Hemorrhage: Third Stage Emergency. Acta Obstetrica et Gynecologica Scandinavica. 2013.

9. Novie M. Perdarahan post partum primer. www.noviemightymax.wordpress. com/2012/06/15/perdarahan-post-partumprimer/Ihgg.2012.

10. Mochtar R. Perdarahan post partum. http:// www.medlinux.blogspot.com/2009/02/ perdarahan-post-partum.html.2009.

11. Brown HL. Post partum hemorrhage: 11 critical questions, answered by an expert. OBG Management.2011; 23 (1).http://www. obgmanagement.com.

12. Smith JR. Post partum hemorrhage. http:// www.anesthesia.utoronto.ca/edu/cme/ courses/m08/m08p19.htm.

13. Lim PS. Uterine atony: management strategies. Universiti Kebangsaan Malaysia Medical Center. http://www.cdn.intechopen. com/pdfs-wm/32726.pdf.

14. World Health Organization. WHO guidelines for the management of postpartum haemorrhage and retained placenta. Switzerland. 2009.

15. Breathnach F, Geary M. Uterine atony: definition, prevention, nonsurgical management and uterine tamponade. h t t p : / / w w w. wh q libd.who.int / publications/2009/9789241598514_eng.pdf.

16. Aras P, Faisal, Syafri KA. Transfusi masif pada syok hemoragik. Majalah Kedokteran Terapi Intensif. 2014; 4 (2): 22-5 